\title{
37. RESIDUAL GAS CONTENTS OF ORGANIC-RICH CANNED SEDIMENT SAMPLES FROM LEG 23
}

\author{
Richard D. McIver, Esso Production Research Company, Houston, Texas
}

\section{INTRODUCTION}

As part of the continuing program to determine residual gas contents of occasional canned sediment samples from the Deep Sea Drilling Project, six such samples from two sites of Leg 23 were acquired. Organic carbon and residual gas content and composition were determined on these by the same procedures used on previous gas samples (McIver, 1973a). Because of their relatively high organic contents, the samples were also extracted with organic solvents to determine the amount and nature of the bitumens (by previously reported techniques-Gehman, 1962; Koons and Monaghan, 1969). Also a portion of the sample was used for visual description of the solid organic matter by methods adapted from Staplin (1969).

Table 1 contains the data on the samples; Figure 1 shows graphically how the absolute residual gas contents compare with contents of all the other DSDP samples run to date, and Figure 2 shows how the ratio of gas content to organic carbon compares with this same ratio on other DSDP samples.

\section{DISCUSSION}

The organic carbon content of the one sample of detrital clay nanno ooze, Pliocene in age, from Site 222 (off extreme southeast Saudi Arabia in the western edge of the Indus Cone) is normal for deep-sea samples, but the gas content is above average. On the basis of ppm gas per \% organic carbon, the sample is very gassy. Either the organic matter in this sediment is very gas prone, or the sediment has acquired its high gas content from more clay-rich detrital parts of the section.

The upper Pleistocene-Holocene samples from Holes 229 and $229 \mathrm{~A}$, from the southern end of the Red Sea, are rich in organic carbon. These holes were abandoned because of high gas contents, but it appears from our data that the gas is coming from the shallow zones rather than from those penetrated deeper in the holes. The gas contents, virtually all methane, are high in the upper three samples, low in the bottom two. The $165,600 \mathrm{ppm}$ (by volume) of methane in sample No. 3 makes it the second richest gas content in the canned DSDP samples to date-second to the $216,700 \mathrm{ppm}$ in one sample from the Aleutian Trench from Leg 19 (water depth $4552 \mathrm{~m}$, sediment depth $15 \mathrm{~m}$ ) (McIver, 1973b).

Because of their high organic carbon contents, solventsoluble bitumens and hydrocarbons in the samples from Holes 229 and 229A were determined. They had very high bitumen contents. The range from 115 to $415 \mathrm{ppm}$ overlaps the range for the Cariaco Trench cores (Mclver, in press) and the range for the Aleutian Trench cores (McIver, 1973b). The range of ratios of bitumen to organic carbon (113 to 279) of these Red Sea samples also overlaps the range for the Cariaco Trench samples (189 to 571) and are lower than the range for the Aleutian Trench (280 to 530), which means the Site 229 samples are moderately bitumen prone. And, with the ratio of hydrocarbon to bitumen ranging from 0.21 to 0.45 , they are very liquidhydrocarbon prone too; more so than the Cariaco Trench samples ( 0.03 to 0.16$)$ and the Aleutian Trench ones ( 0.03 to 0.28 ). While the visual description (i.e., alteration values) suggests that these samples are not very far along in the process of petroleum-hydrocarbon generation, the hydrocarbon-to-bitumen ratios suggest that the process has started. Perhaps the bitumen deposited here was very susceptible to low temperature conversion to hydrocarbons because the ratios are high for typical near mud-line deep-water sediments and because the absolute amounts of $\mathrm{C}_{15}+$ hydrocarbon are in the range that has been interpreted as being characteristic of potential source rocks of petroleum (Philippi, 1956).

In conclusion, based on only one sample, it appears that, locally, sediments in the distal portion of the Indus Cone may be gas rich. Sediments from 51 to 175 meters in the southern end of the Red Sea seem to indicate an environment very conducive to the formation of gaseous and liquid hydrocarbons.

\section{ACKNOWLEDGMENTS}

Special recognition is due Ralph Pokluda, Jim Morgan, Shirley Tillotson, Harvey Fry, and Tom Conary who assisted with sample handling and analyses, and to Esso Production Research Company for their continuing support of this work and their permission to prepare and publish this report.

\section{REFERENCES}

Gehman, H. M., Jr., 1962. Organic matter in limestones: Geochim. Cosmochim. Acta, v. 26, p. 885.

Koons, C. B. and Monaghan, P. H., 1969. Data and discussion of analyses, including $\mathrm{C}^{12} / \mathrm{C}^{13}$ ratios. In Ewing, M. W. et al., Initial Reports of the Deep Sea Drilling Project, Volume I: Washington (U. S. Government Printing Office), p. 478.

McIver, R. D., 1973a. Hydrocarbon gases from canned core samples, Sites 174A, 176 and 180. In Kuhn, L. D., von Huene, R., et al., Initial Reports of the Deep Sea Drilling Project, Volume XVIII: Washington (U.S. Government Printing Office), p. 1013.

1973b. Hydrocarbons in canned muds from Sites $185,186,189$, and $191-$ Leg 19. In Creager, J. S., Scholl, D.W., et al., Initial Reports of the Deep Sea Drilling Project, Volume XIX: Washington (U.S. Government Printing Office), p. 875. 


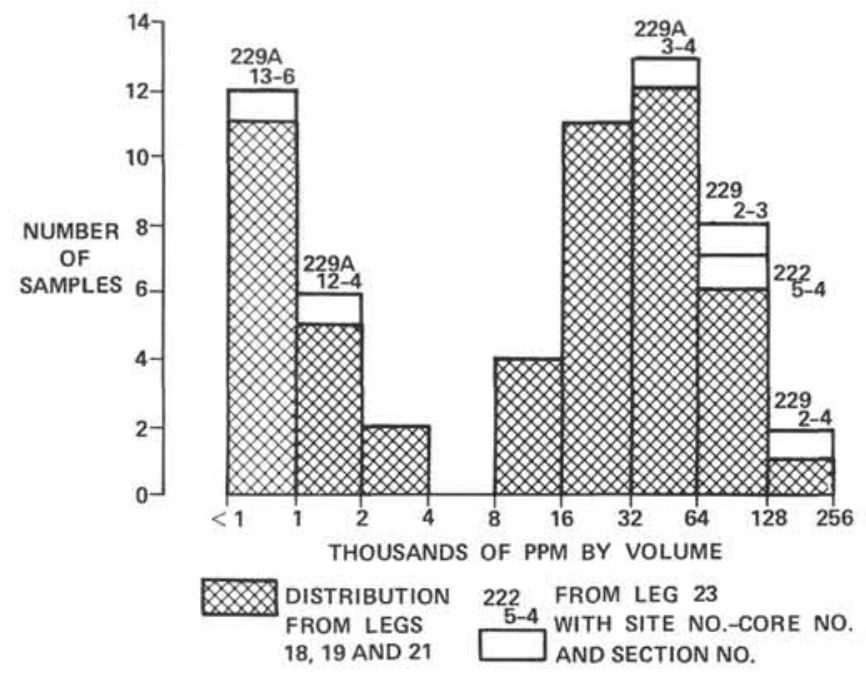

Figure 1. Range of residual hydrocarbon gas contents of Leg 23 canned muds compared with previous results.

in press. Cyclical geochemical properties of organic matter in Cariaco Trench cores-Leg 15, Site 147B and 147C. In Heezen, B. C., MacGregor, I. et al., Initial Reports of the Deep Sea Drilling Project, Volume XX: Washington (U. S. Government Printing Office).

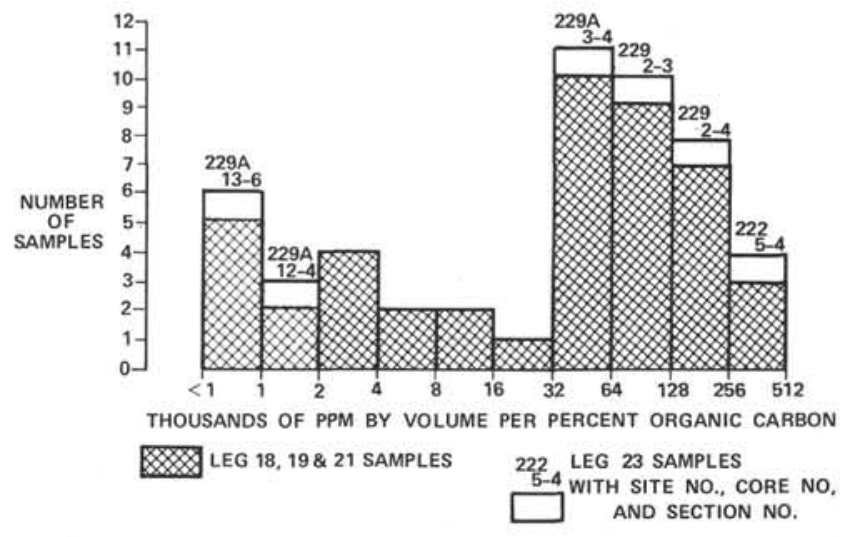

Figure 2. Range of ratios of residual gas contents $t \mathrm{c}$ organic carbon contents of Leg 23 canned muds versus previous samples.

Philippi, G. T., 1956. Identification of oil source beds by chemical means: Intern. Geol. Congr. 29th, Mexico, 1956, Rept. 25.

Staplin, F. L., 1969. Sedimentary organic matter, organic metamorphism and oil and gas occurrence: Canadian Petrol. Geol. Bull., v. 17, p. 47. 
TABLE 1

Organic Geochemical Data, Leg 23 Canned Sediment Samples

\begin{tabular}{|c|c|c|c|c|c|c|c|c|c|c|c|c|c|c|c|}
\hline \multirow[b]{2}{*}{ Shipboard Description } & \multirow[b]{2}{*}{ Sample } & \multirow[b]{2}{*}{ Hole } & \multirow[b]{2}{*}{ Core } & \multirow[b]{2}{*}{$\begin{array}{l}\text { Section } \\
(\mathrm{cm})\end{array}$} & \multirow{2}{*}{$\begin{array}{l}\text { Water } \\
\text { Depth } \\
\text { (m) }\end{array}$} & \multirow{2}{*}{$\begin{array}{l}\text { Depth in } \\
\text { Sediment } \\
\text { Column } \\
(\mathrm{m})\end{array}$} & \multirow{2}{*}{$\begin{array}{l}\text { Organic } \\
\text { Carbon } \\
(\%)\end{array}$} & \multirow{2}{*}{$\begin{array}{l}\text { Methane } \\
\text { (ppm } \\
\text { by vol) }\end{array}$} & \multirow{2}{*}{$\begin{array}{l}\text { Solvent- } \\
\text { Soluble } \\
\text { Bitumens } \\
\text { (ppm } \\
\text { by wt) }\end{array}$} & \multirow{2}{*}{$\begin{array}{c}\mathrm{C}_{15+} \\
\text { Hydrocarbons } \\
\text { (ppm by wt.) }\end{array}$} & \multirow{2}{*}{$\begin{array}{c}\mathrm{C}_{15+} \\
\text { Hydrocarbon } \\
\text { Saturate/ } \\
\text { Aromatic } \\
\text { Ratio }\end{array}$} & \multicolumn{3}{|c|}{$\begin{array}{l}\text { Visual Description of } \\
\text { Insoluble Organic Matter }\end{array}$} & \multirow{2}{*}{$\begin{array}{c}\text { Alteration } \\
1 \text {-unaltered } \\
5 \text {-carbonized }\end{array}$} \\
\hline & & & & & & & & & & & & $\begin{array}{c}\text { Primary } \\
\text { Type }\end{array}$ & $\begin{array}{l}\text { Secondary } \\
\text { Type }\end{array}$ & $\begin{array}{c}\text { State of } \\
\text { Preservation }\end{array}$ & \\
\hline $\begin{array}{l}\text { Gray detrital clay- } \\
\text { nanno ooze }\end{array}$ & 1 & 222 & 5 & $4-?$ & 3546 & 142 & 0.28 & 88,900 & $\mathrm{~N} / \mathrm{A}$ & N/A & - & - & - & - & - \\
\hline $\begin{array}{l}\text { Olive gray, pteropod- } \\
\text { bearing, clay-rich } \\
\text { nanno carbonate ooze }\end{array}$ & 2 & 229 & 2 & $3-0$ & 852 & 59 & 0.94 & 84,500 & 138 & 72 & 1.07 & Amorphous & $\begin{array}{l}\text { Algal } \\
\text { debris }\end{array}$ & Very poor & 1 \\
\hline Same as above & 3 & 229 & 2 & $4-50$ & 852 & 61 & 1.14 & 165,600 & 230 & 58 & 0.83 & Amorphous & Woody & Very poor & $1-2$ \\
\hline $\begin{array}{l}\text { Same as above but } \\
\text { light olive color - } \\
\text { strong } \mathrm{H}_{2} \mathrm{~S} \text { odor, gassy }\end{array}$ & 4 & $229 \mathrm{~A}$ & 3 & 4-0 & 852 & 51 & 1.01 & 32,600 & 237 & 63 & 0.85 & Amorphous & Woody & Very poor & 1 \\
\hline $\begin{array}{l}\text { Foram-bearing silty } \\
\text { clay and carbonate-rich } \\
\text { nanno ooze and chalk }\end{array}$ & 5 & $229 \mathrm{~A}$ & 12 & $4-?$ & 852 & 163 & 0.67 & 1,000 & 115 & 52 & 1.02 & Amorphous & Woody & Very poor & $1-2$ \\
\hline $\begin{array}{l}\text { Zeolite-bearing clay- } \\
\text { and carbonate-rich } \\
\text { nanno ooze and chalk }\end{array}$ & 5 & $229 \mathrm{~A}$ & 13 & $6-150$ & 852 & 175 & 1.18 & 700 & 415 & 88 & 1.59 & Amorphous & Woody & Very poor & $1-2$ \\
\hline
\end{tabular}

